DOI https://doi.org/10.30525/978-9934-588-91-4-6

\title{
ФЕНОМЕН «ГІБРИДНОЇ УДЕНТИЧНОСТІ» Г. БГАБГА ЯК КОНЦЕПТ НОВОЇ КУЛЬТУРНОЇ РЕАЛЬНОСТІ
}

\author{
Слоневська I. Б. \\ кандидат філософських наук, доцент, \\ завідувачка кафедри культурологї̈ та зарубіжної літератури \\ Хмельницької гуманітарно-педагогічної академії \\ м. Хмельницький, Україна \\ Пірошенко С. Ю. \\ кандидат філологічних наук, дочент, \\ доцент кафедри культурологї та зарубіжної літератури \\ Хмельницької гуманітарно-педагогічної академії \\ м. Хмельницький, Украӥна
}

Калашнік О. В.

кандидат філософських наук,

старший викладач кафедри культурології та зарубіжної літератури

Хмельницької гуманітарно-педагогічної академії

м. Хмельницький, Украӥна

У сучасному світі відбувається активна трансформація теорій мультикультуралізму. Звідси особливий науковий інтерес до постколоніальних студій, які становлять важливий напрям сучасної гуманітаристики. Постколоніальні теорії тісно пов'язані з філософськими поглядами найпомітніших дослідників сучасного соціокультурного дискурсу. Зокрема, у центрі постколоніальних досліджень виявляється феномен гібридної ідентичності, який активно досліджується як один з визначальних концептів нової культурної реальності.

Власне, сам «вибух постколоніальності», як його іноді називають, відбувся в 1979 році після виходу книги «Орієнталізм» Едварда Ваді Саїда (E. W Said, Orentalism, 1978) [2], американського літературного критика палестинського походження, політичного активіста, якого сьогодні вважають одним з засновників постколоніальної теорії. Як окремий напрям гуманітарних досліджень, постколоніальна проблематика ствердилась в 90-ті роки XX століття, чому особливо посприяли дослідження Едварда Саїда «Культура і імперіалізм» (Culture and Imperialism, 1993) [2], Гаятрі Чакраворті Співак «В інших світах» (Spivak, G. C., In other worlds: Essays in cultural politics, 1987) [3] та особливо праці Гомі Бгабга (H. Bhabha) [1]. Дослідження останнього (професора гуманітарних наук Гарвардського університету, керівника 
Гуманітарного центру у Гарварді та професора гуманітарних наук в Університетському коледжі Лондона, індійця за походженням) утворили засади для осмислення феномену постколоніалізму сучасною гуманітаристикою: «Нація та нарація» (Nation and Narration, 1990), «Місцезнаходження культури» (Location of Culture, 1993), «Космополітизм» (Cosmopolitanisms, 2000) тощо. Бгабга $є$ автором багатьох ключових понять сучасної постколоніальної теорії, таких як гібридність, мімікрія, амбівалентність.

Якщо Едвард Саїд артикулював поняття орієнталізму як дискурсу, у якому європейська культура визначила себе 3 позиції явної переваги, а європейська культурна традиція сформувалася занадто «євроцентричною» і зверхньою щодо свого погляду на Схід, то, на відміну від колеги, Гомі Бгабга запропонував ідею «ефективної культурної гібридності», своєрідного «стану за межами» [1]. Бгабга розглядає межі культур як мобільні, рухомі, зазначає, що відтворення культури «за межами» стає художньою стратегією нашого часу, наративом перехідного стану життя на «порубіжжі» [1]. Це стан суб'єкта, котрий відчуває свою причетність до двох або й більше культур, але до жодної з них не належить повністю. Цей стан дослідник визначає як «позадомність» (unhomeliness): суб'єкт, звертаючись у пошуках своєї ідентичності до власного коріння, уже не має можливості бути цілковито своїм «у домі», адже відчув на собі вплив колонізатора і іншої мета культури; проте і в цій культурі метрополії він не став своїм, а залишається гостем, екзотичним прибульцем зі Сходу, отож, змушений опановувати новий простір «між» (in between).

Окрім того, привертає увагу, що, аналізуючи концепт ідентичності, Бгабга не розглядає його як статичний, підкреслюючи, що у сучасному світі він $\epsilon$ результатом та наслідком багатогранного інтерактивного процесу, який може відбуватися протягом усього життя. Позицію Бгабги певною мірою поділяє Сейла Бенхабіб, одна 3 найвідоміших сучасних дослідників мультикультуралізму та його особливостей $\mathrm{i}$ принципів, що знайшло відображення в найрезонанснішій праці авторки «Домагання культури. Рівність і різноманітність у глобальну epy» (Seila Benhabib, The Claims of Culture: Equality and Diversity in the Global Era, 2002), яка привертає увагу, зокрема, тим, що в ній дослідниця осмислює позицію культурної екзистенції людини, яка знаходиться «на перетині культур».

Саме цей «межовий» стан Бгабга позиціонує як гібридну ідентичність, яка, на думку дослідника, визначає характер сучасної культури i має більший потенціал у сучасному світі, позаяк анулює домінуючий вплив однієї культури і дозволяє суб'єкту виявляти риси приналежності до обох світів і в той же час не вписуватися в жоден 3 них. Загальний культурний дискурс межі століть та особливо XXI століття є дедалі більш дистанційованим від моделі біполярного світу, а отже, феномен 
гібридної ідентичності визначає наратив життя «на порубіжжі» i розглядається як один із найпереконливіших концептів культурної реальності доби після-постмодерну.

\section{Література:}

1. Бхабха Х. Местонахождение культуры / Хоми Бхабха [пер. с английского Глеба Гобзема] Перекрестки. Журнал исследований восточноевропейского пограничья. URL: https://andrewrosdolsky.blogspot.com/ 2016/11/3-42005-161-192.html (дата звернення 25.09.2020).

2. Саид Э. Ориентализм [Orientalism]. URL: http://www.ihavebook.org/ books/226362/orientalizm.html (дата звернення 25.09.2020).

3. Spivak, G.C. In other worlds: Essays in cultural politics. URL: https://bit.ly/2TrfzTn (дата звернення: 23.09.2020). 